\title{
Studies on some East Indian Hepaticae.
}

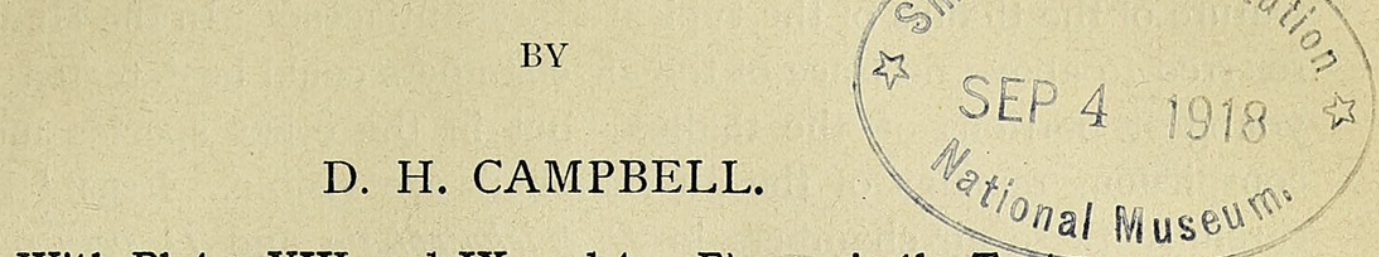

With Plates VIII and IX and ten Figures in the Text.

\section{DUMORTIERA.}

THE genus Dumortiera is common throughout the humid tropics of both hemispheres, and extends into the warm temperate regions as well. Thus D. hirsuta occurs in the British Isles, Japan, and the SouthEastern United States.

The anatomy of the thallus has been pretty completely investigated and will not be dwelt upon at length., 2 Very little, however, has been done upon the development of the reproductive organs and sporophyte.

Collections have been made by the writer in various parts of the IndoMalayan region. These were mostly of the widely distributed species, $D$. trichocephala, Hook., but the much more local species, D. velutina, Schiffn., was also collected, as well as what appears to be an undescribed species from Sarawak in Borneo.

From a study of these collections it was possible to secure a fairly satisfactory series of preparations showing the most important points in the development of the sexual organs and sporophyte.

Stephani ${ }^{3}$ recognizes but three species of the genus, of which $D$. trichocephala is widely distributed throughout the Indo-Malayan region and Oceanica, while $D$. hirsuta (Sw.), R. Bl., is widespread in both hemispheres. The very distinct $D$. velutina, Schiffn., is known only from Java and Sumatra. Immature specimens of Dumortiera, collected by the writer in Hawaii during the past summer, may possibly belong to this species.

In I 892 the writer collected in Hawaii sterile specimens of a Dumortiera which was identified by the late Professor L. M. Underwood as D. trichocephala. ${ }^{3}$ The thallus in this form is quite destitute of even the rudiments of air-chambers, thus differing from all the other species that have been

1 Leitgeb : Untersuchungen über die Lebermoose, vi. Graz, I88I.

Ernst, A.: Untersuchungen über Entwicklung, Bau und Verteilung der Inflorescenzen von Dumortiera. Ann. Jardin Bot. Buitenzorg, $2^{\mathrm{e}}$ sér., vii, 1908 , pp. $\mathbf{I}_{53^{-2} 2} 3^{\text {. }}$

2 Stephani, F. : Species Hepaticarum. Bull. L'Herbier Boissier, vii, r899, pp. 22 2-5.

- See Campbell : Mosses and Ferns, 2nd edition, p. 49.

[Annals of Botany, Vol. XXXII. No. CXXVII. July, 1918.] 
investigated. Fertile material of this form, which is very abundant in many parts of Hawaii, was collected by the writer during the past summer, and it is doubtful whether it can properly be referred to D. trichocephala.

All of the species of Dumortiera are characterized by a more or less complete suppression of the air-chambers which are so conspicuous a feature of the thallus of the typical Marchantiaceae. In the Hawaiian form referred to above, no trace of the air-chambers could be detected, even in the youngest portions of the thallus; but in the other species more or less conspicuous remains of the air-chambers are visible. Ernst ${ }^{1}$ has studied carefully these air-chambers in $D$. trichocephala and $D$. velutina, and the writer can confirm his results from an examination of material from the same localities in Java where Ernst collected his specimens.

In $D$. velutina not only are the air-chambers very evident near the apex of the thallus, but the green tissue found in the air-chambers of the typical Marchantiaceae is represented by crowded papillate cells which completely cover the surface of the thallus and give it a characteristic velvety texture, very different from the greasy-looking, olivaceous, nearly smooth surface in $D$. trichocephala. In the latter the papillate cells are either completely absent or very sparingly scattered over the surface.

In all species the epidermis is completely wanting except in the youngest parts of the thallus; but the lateral walls of the air-chambers may persist more or less completely so as to form an irregular reticulation on the surface comparable to that present in the typical Marchantiaceae (see Pl. VIII, Fig. 3).

The development of the air-chambers is, to some extent at least, associated with the environment. ${ }^{2}$ When the conditions are comparatively dry the air-chambers are better developed than in a very wet situation, and excessive moisture may cause a complete suppression of the air-chambers. Of the species considered in the present paper, D. calcicola, which grows under relatively dry conditions, has the air-chambers comparatively well developed.

That moisture is not the only factor concerned, however, is probable. During the past summer the writer collected two species of Dumortiera in Hawaii not infrequently growing together, one of which had conspicuous reticulations on the surface of the thallus, while the other showed no trace of air-chambers.

\section{The Reproductive Organs.}

As in other Marchantiaceae, the sex-organs in Dumortiera are borne on the characteristic receptacles. The male receptacle (Pl. VIII, Fig. 6, H ; Text-fig. 2, c) is a nearly flat disc, borne upon a very short pedicel. The female receptacle, or carpocephalum, is more or less conspicuously convex, and at

1 Loc. cit.

${ }^{2}$ Coker, W. C. : Selected Notes, II. Bot. Gaz., xxxvi, 1903, pp. 225-30. 

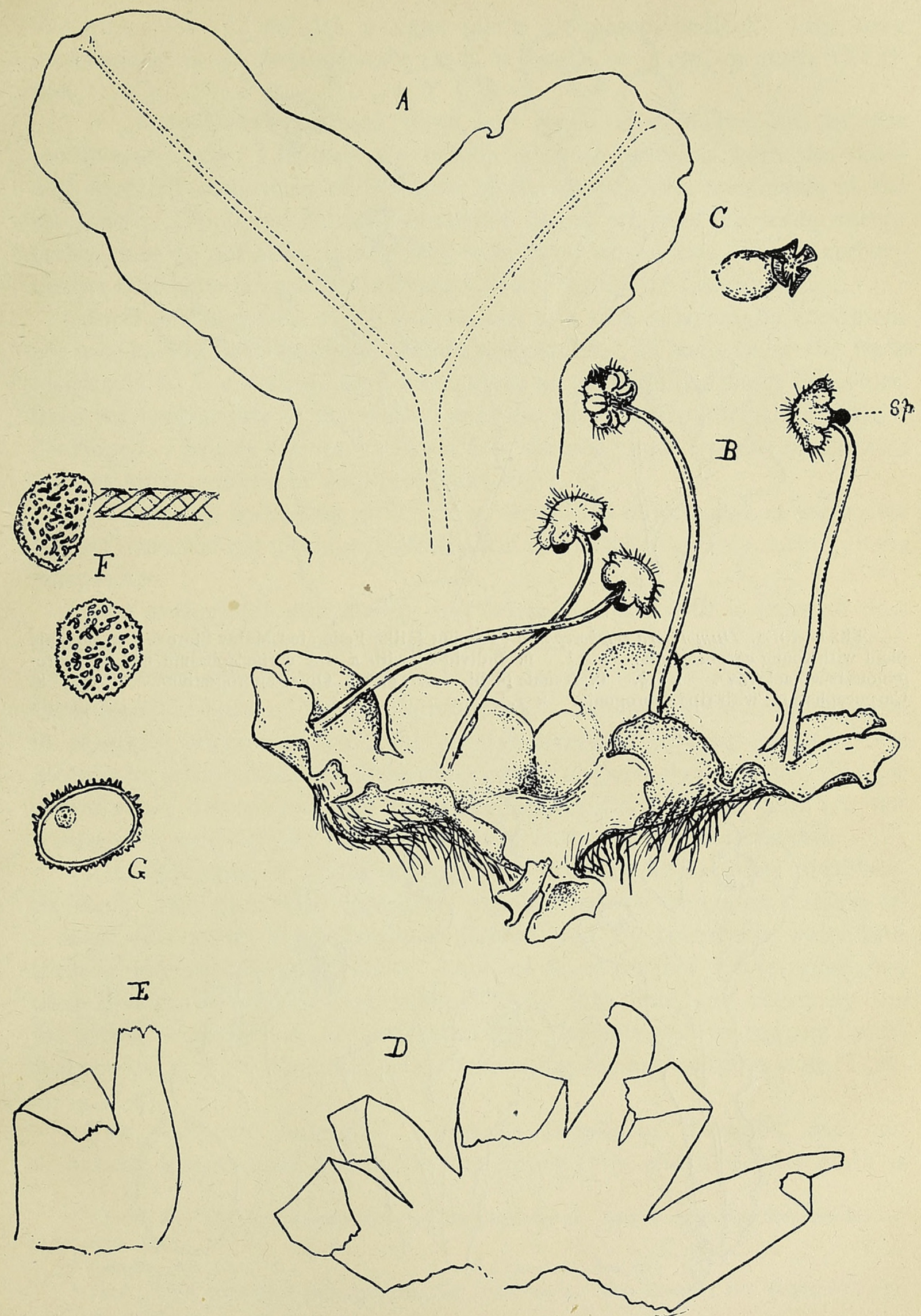

Text-Fig. I. Dumortiera trichocephala, Hook. A. Large sterile specimen from Luzon, Philippine Islands. $\times \mathbf{I}_{\frac{1}{3}}$. B. Fertile plant from Tjibodas, Java. $\times \mathrm{I}_{\frac{1}{3}}$. C. Open sporogonium. $\times 3 \frac{1}{3}$. D, E. Open capsule, showing the deeply divided valves. $\times 20$. F. Ripe spores and part of an elater. $\times 575$. G. Section of ripe spore. $\times 575$. 


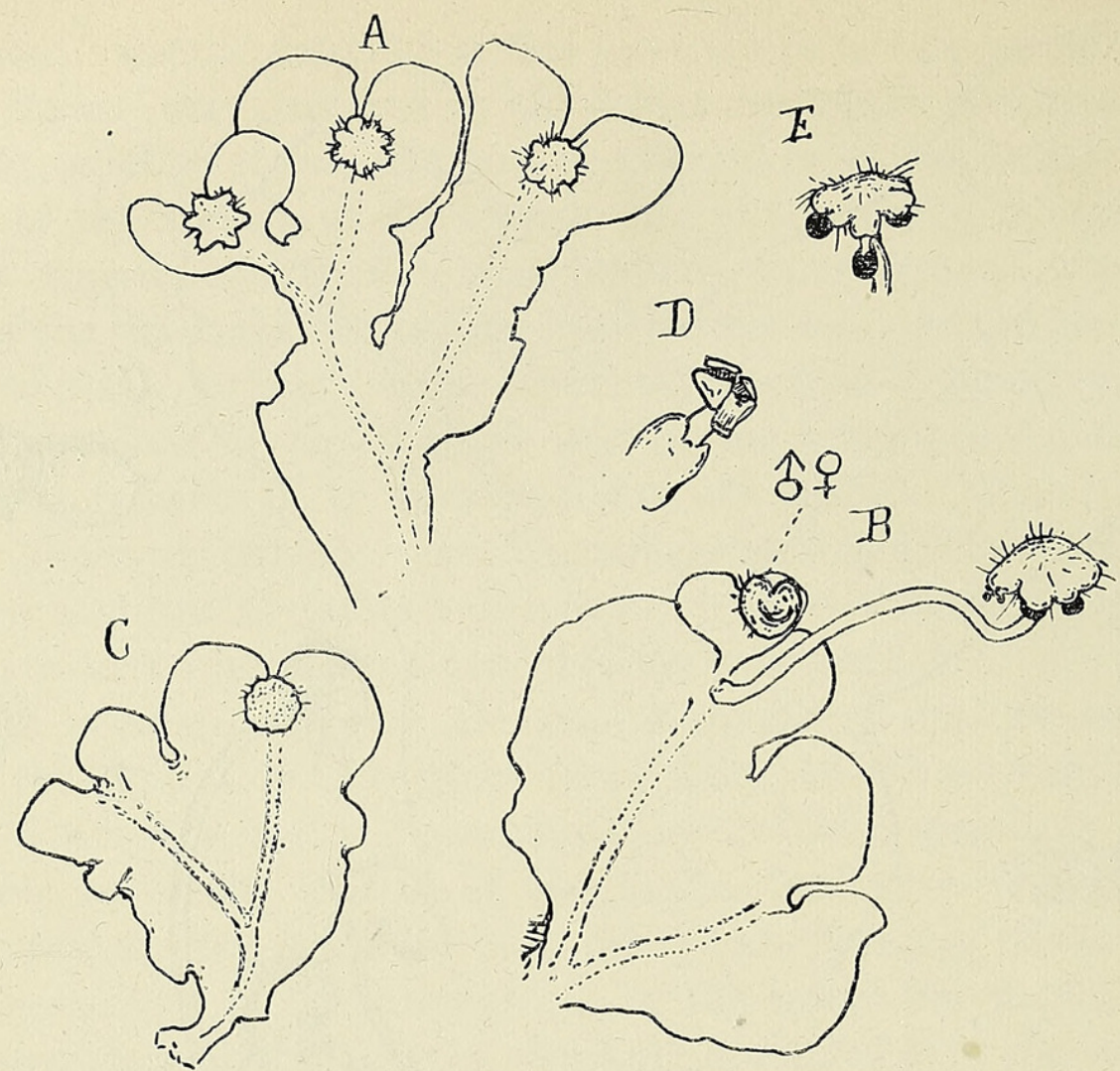

TexT-FIG. 2. Dumortiera trichocephala (Taiping Hills, Federated Malay States). A. Female plant with young carpocephala. $\times I \frac{1}{3}$. B. Individual with a ripe carpocephalum and an andro-

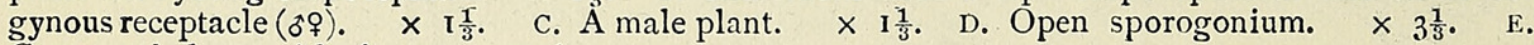
Carpocephalum, with ripe sporogonia. $\times 2$.
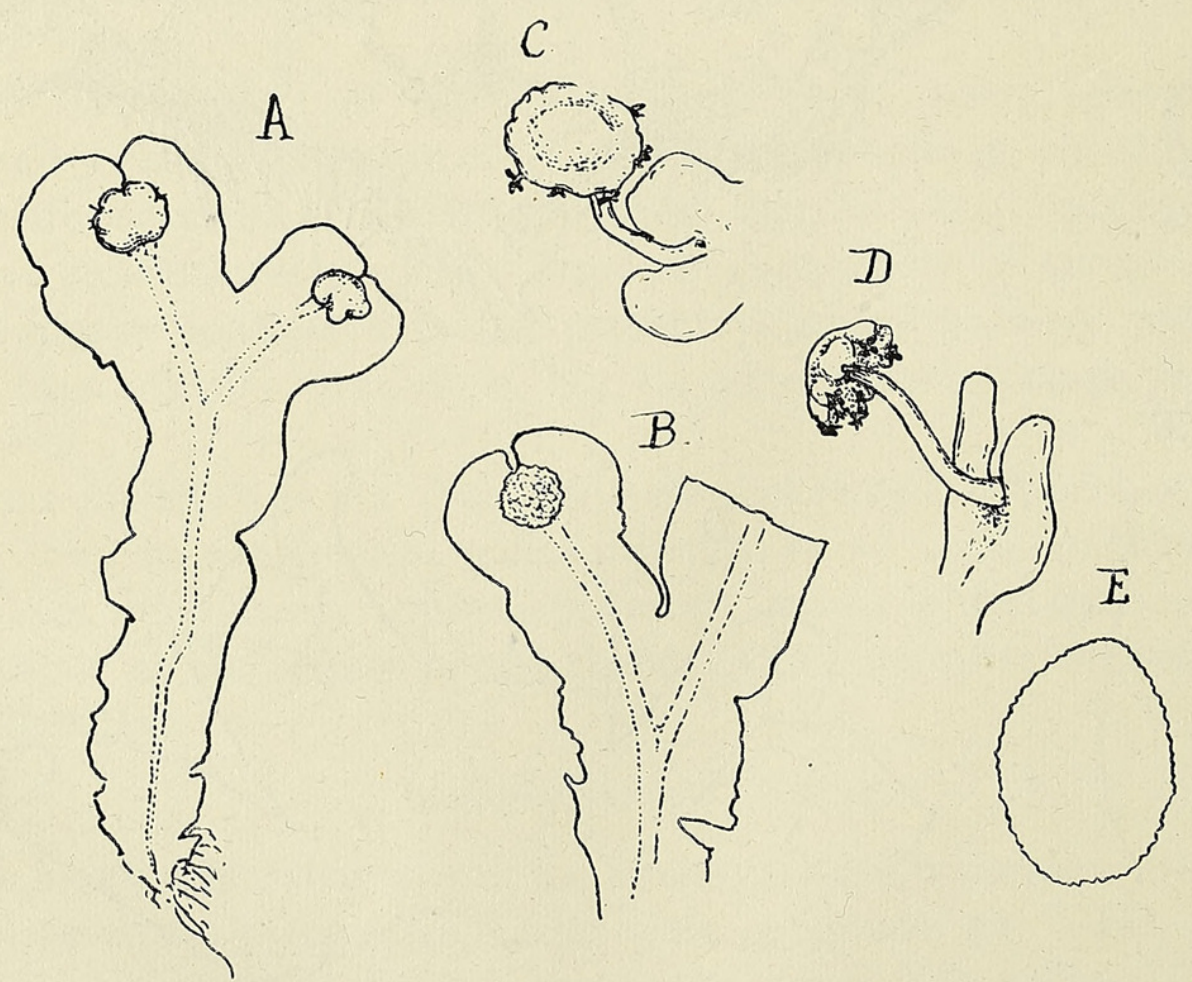

TEXT-FIG. 3. Dumortiera velutina, Schiff. A. Female plant with young carpocephala. $\times \mathbf{I}_{3}^{\frac{1}{3}}$. B. Male plant. $\times \mathbf{I} \frac{1}{3}$. c, D. Mature carpocephala. $\times 2$. E. Ripe spore. $\times 575$. 
maturity there is usually a very much elongated pedicel. This may occasionally in $D$. trichocephala reach a length of $7 \mathrm{~cm}$. or more (Textfigs. $1,2,3)$.

It is evident that both male and female receptacles are of the 'composite' type; i. e. they are branch systems resulting from the rapid and repeated dichotomy of the apex of the shoot which terminates in the receptacle. To judge from a somewhat casual study of the young receptacles, they do not differ in any way from those of various other Marchantiaceae that have been described (see Cavers, ${ }^{1}$ Leitgeb, ${ }^{2}$ Campbell ${ }^{3}$ ).

In $D$. trichocephala, which is dioecious as a rule, occasionally specimens are met having both male and female receptacles. In such cases the male receptacle is first formed, and later, upon an adventitious shoot developed from the ventral side of the thallus, near the apex, a carpocephalum may be developed. In this species, as Ernst first showed, ${ }^{4}$ androgynous receptacles are not infrequently met with (see Text-fig. 2, B).

$D$. velutina, according to Schiffner, ${ }^{5}$ is always dioecious, and the writer has not observed monoecious individuals in this species, nor any androgynous receptacles.

The antheridial receptacles are flattened discs with a more or less marked central depression (Text-fig. 4, A). The pedicel is very short. On the lower side of the receptacle are formed narrow scales much like those near the apex of the sterile branches. The antheridia are developed in acropetal succession from the several marginal growing points of the receptacle, arising from the dichotomy of the original shoot-apex. There is considerable displacement of the older antheridia, so that they are not arranged in such definite radiating rows as is the case in Marchantia.

The development of the antheridium is much as in other Marchantiaceae. ${ }^{6}$ The somewhat elongated papillate mother-cell, after cutting off a basal cell, as in Marchantia, is divided first by transverse walls into three or four superimposed cells. Each of these (except the terminal one) then divides, by intersecting vertical walls, into four, and these, by the formation of periclinals, are separated into the inner spermatogenic tissue, and the outer layer of sterile cells constituting the antheridium wall (Textfig. $4, \mathrm{~B}-\mathrm{E})$.

The stalk-cell undergoes numerous transverse divisions, with an occasional longitudinal division in the upper cells, and a slender stalk is

1 Cavers, F.: The Inter-relationships of the Bryophyta. New Phytologist, Reprint, No. 4, Cambridge, I9II.

2 Leitgeb : loc. cit.

3 Campbell : loc. cit.

4 Ernst: Über androgyne Inflorescenzen bei Dumortiera. Ber. Deutsch. Bot. Gesellsch., xxv, I 906, pp. $455^{-6} 4$.

5 Schiffner: Die Hepaticae der Flora von Buitenzorg, xxvi. Leiden, $\mathbf{1} 900$.

6 Strasburger: Die Geschlechtsorgane und die Befruchtung bei Marchantia polymorpha. Pringsh. Jahrb., v, 1866-7, p. 297. Campbell : loc. cit., pp. 49-53. 


\section{Campbell.-Studies on some East Indian Hepaticae.}

thus formed (Text-fig. 4, F, G). This elongated stalk is unusual among the Marchantiaceae, but has been also noted in Targionia. ${ }^{1}$

The apex of the antheridium becomes elongated and forms a conspicuous beak (Text-fig. 4 F, G).
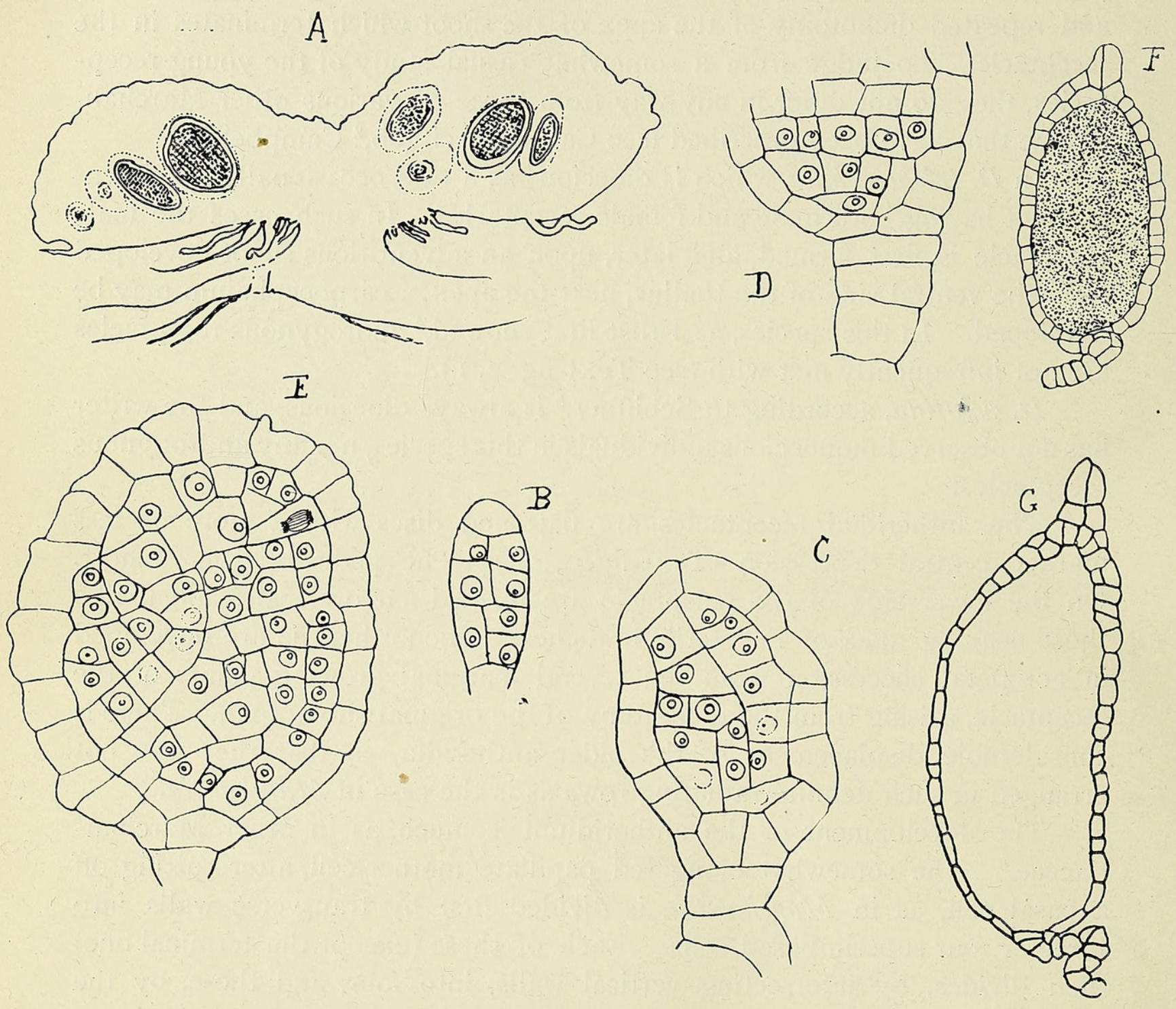

TEXT-FIG. 4. A. Section of an antheridial receptacle of D. trichocephala $\times 35 . \quad B-E$. Young antheridia of $D$. trichocephala. $\times 35^{\circ}$. F. Ripe antheridium. $\times 65$. G. Antheridium of D. velutina. $\times 6_{5}$.

The development of the spermatozoids was not investigated in detail, but the last division of the spermatocytes is not diagonal as Ikeno ${ }^{2}$ describes for Marchantia, and the sperm-cells are not so evidently in pairs; indeed it looks as if there might perhaps be one less division than is the case in Marchantia. The spermatozoids are decidedly larger than in any

1 McFadden, Effie B. : Bull. Torr. Bot. Club, vol. xxiii, I896, pp. 242-4.

2 Ikeno, S. : Die Spermatogenese von Marchantia polymorpha. Beiheft 3, Bot. Centralbl., vol. $\mathrm{xv}, \mathrm{I}_{903}, \mathrm{pp} .6_{5}-88$. 
other Marchantiaceae examined by the writer, but there was no indication of any marked difference in their structure from what has been observed in other Hepaticae.

The antheridium as usual is contained in a chamber opening by a narrow pore, and presumably the dehiscence of the antheridium and the discharge of the spermatozoids are effected as in other Marchantiaceae. ${ }^{1}$

\section{The Carpocephalum.}

The female receptacle, or carpocephalum, is easily shown to be of the composite type, its pedicel being a prolongation of the axis of the shoot upon which it is borne. Sections through the young receptacle show clearly its compound structure, there being several $(6-7)$ apices, each giving rise to a group of archegonia. The receptacle from the first is convex, and the excessive dorsal growth pushes the growing points below the margin of the receptacle so that the archegonia, which really are dorsal structures, seem to arise from the ventral surface of the receptacle. In short, the growth of the carpocephalum resembles exactly that of the other Marchantiaceae (Textfig. $5, \mathrm{~A}, \mathrm{~B})$. The compound nature of the receptacle is sometimes very evident superficially, as its margin may be deeply lobed, each lobe corresponding to a growing point with its group of archegonia. This was especially noticeable in specimens of $D$. trichocephala from the Taiping Hills in the Malay Peninsula (Text-fig. 2, A). The plants were smaller than those collected in Java and the pedicel of the ripe carpocephalum shorter. In $D$. velutina (Text-fig. 3 ) the pedicel is also decidedly shorter than it is in D. trichocephala.

The development of the archegonium is much like that of the other Marchantiaceae. The first division in the mother-cell (Text-fig. 5, c) divides it into a basal tapering stalk-cell and an upper hemispherical cell, which presently undergoes the usual division by three intersecting vertical walls into an axial cell and three peripheral ones. From the former is cut off the primary cap-cell, and the inner cell ultimately produces the egg and the axial row of canal-cells. From the outer cells develop the wall of the venter and the six rows of neck-cells. Sooner or later the cap-cell divides by two intersecting walls, but there are several secondary divisions in the cap-cells, so that more than four cover-cells finally are formed. This is very much like the condition observed in certain species of Riccia ${ }^{2}$ as well as in a number of other Hepaticae. The cells of the venter-wall show no

1 See Peirce, G. J. : Forcible Discharge of Antherozoids in Asterella Californica. Bull. Torr. Bot. Club, vol. xxix, 1902, pp. 374-82.

Cavers, F. : Explosive Discharge of Antherozoids in Fegatella conica. Ann. of Bot., vol. xvii, I903, p. 270.

2 Campbell : loc. cit., p. 30. 
periclinal divisions in the mature archegonium. The number of neck canalcells was not determined with certainty, but is probably six or eight.

The neck of the archegonium in $D$. trichocephala is strongly bent upward when mature, this being probably the result of the position of the
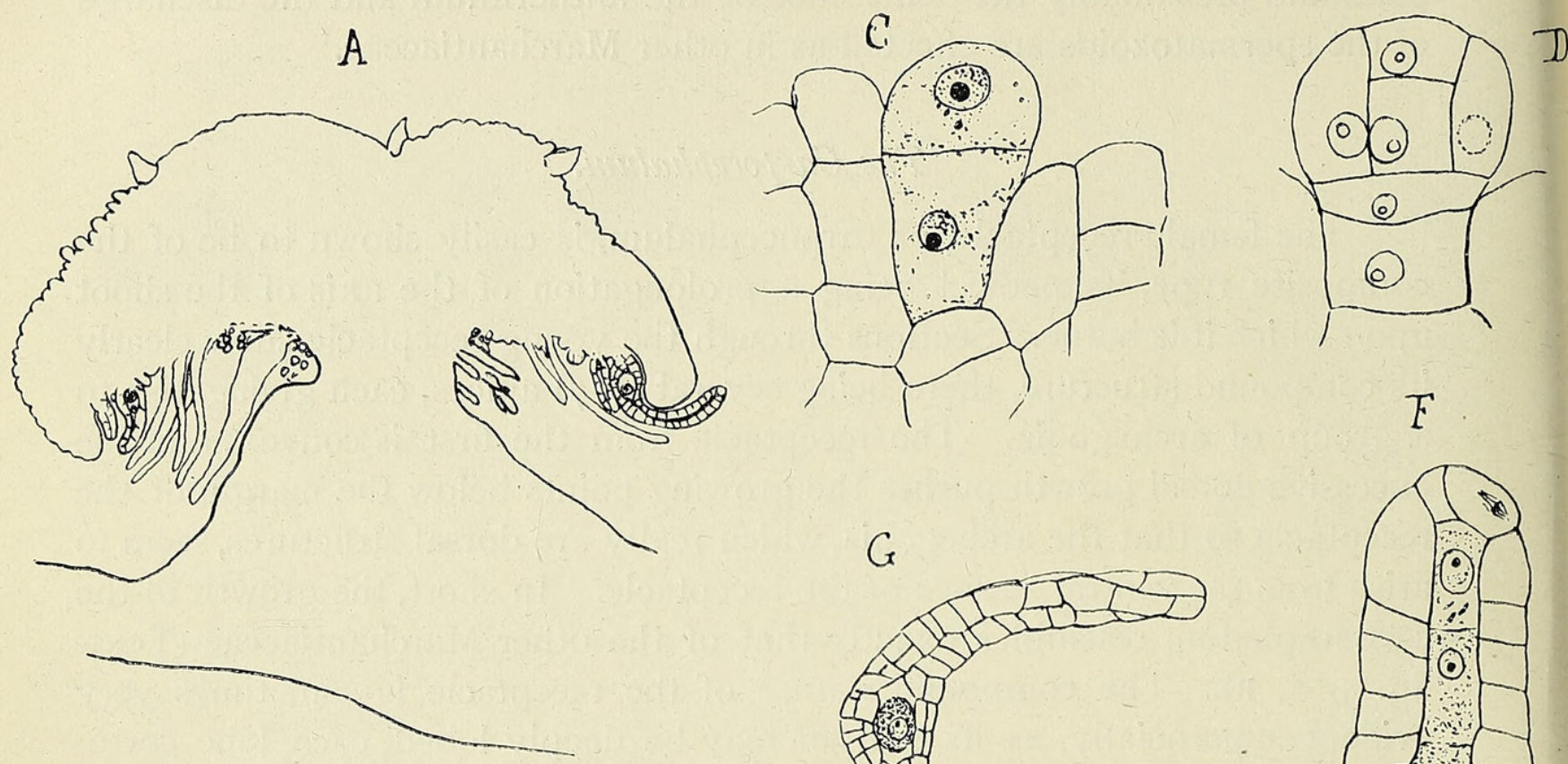

B
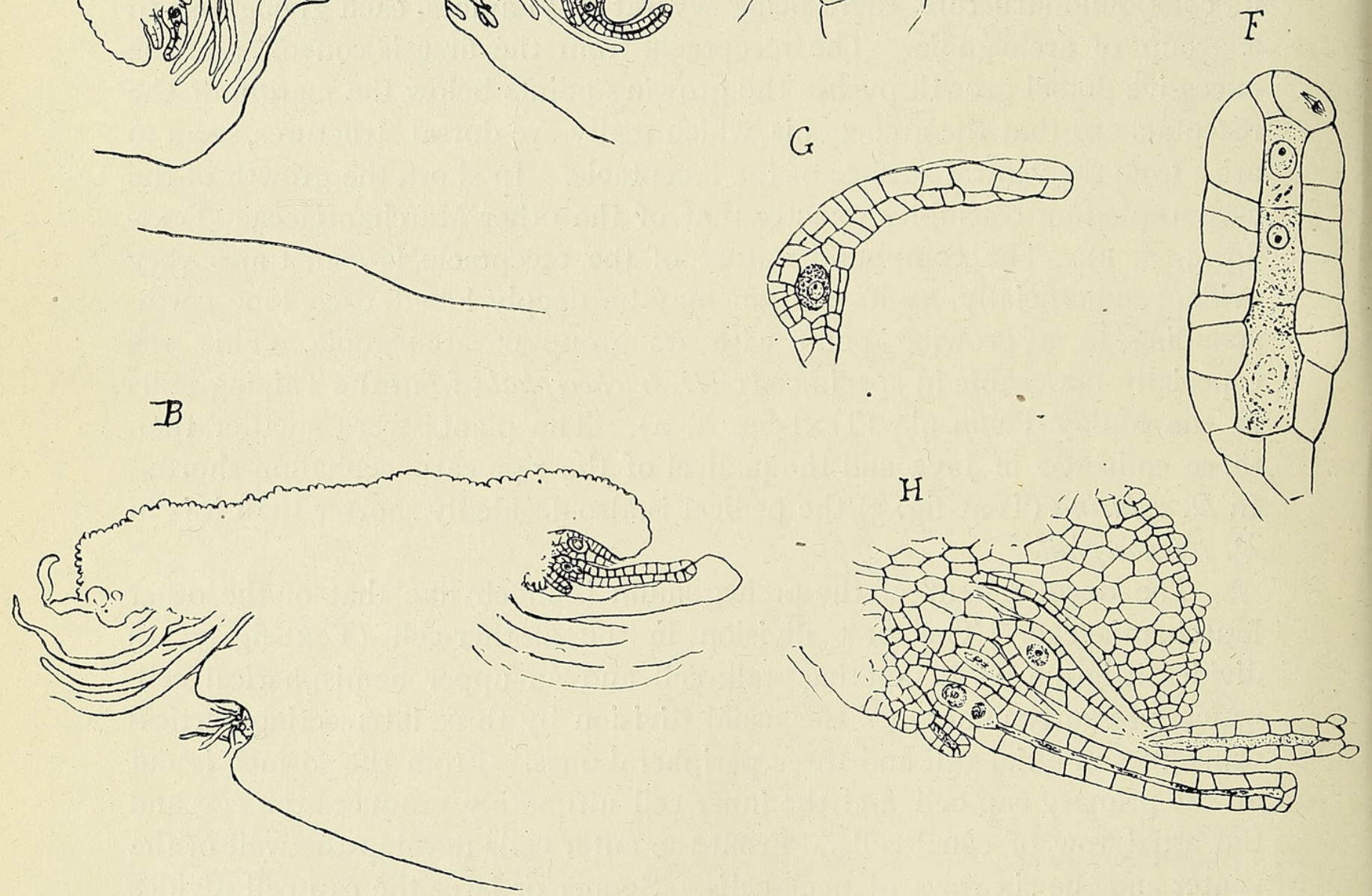

Text-Fig. 5. A. Section of young carpocephalum of D. trichocephala. $\times 35$. B. Similar section of D. velutina. $\times 35 . \quad$ C, D. Young archegonia of D. trichocephala. $\times 560 . \quad$ F. An older archegonium. $\times 480 . \quad$ G. Ripe archegonium. $\times 100$. H. Archegonia of D. velutina. $\times 95$.

archegonia, which are pushed completely to the lower side of the receptacle by excessive growth of the dorsal tissue (Text-fig. 5, G). In D. velutina, where the receptacle is much less convex, the archegonia lie almost horizontally, and the neck is nearly straight (Text-fig. 5, B, H).

No perianth or other envelope is formed about the archegonia. Rhizoids and irregular narrow scales are developed upon the ventral 
surface of the receptacle. A cross-section of the pedicel of the receptacle shows two furrows filled with slender rhizoids.

The Sporophyte.

So far as we have been able to discover, no account of the embryogeny

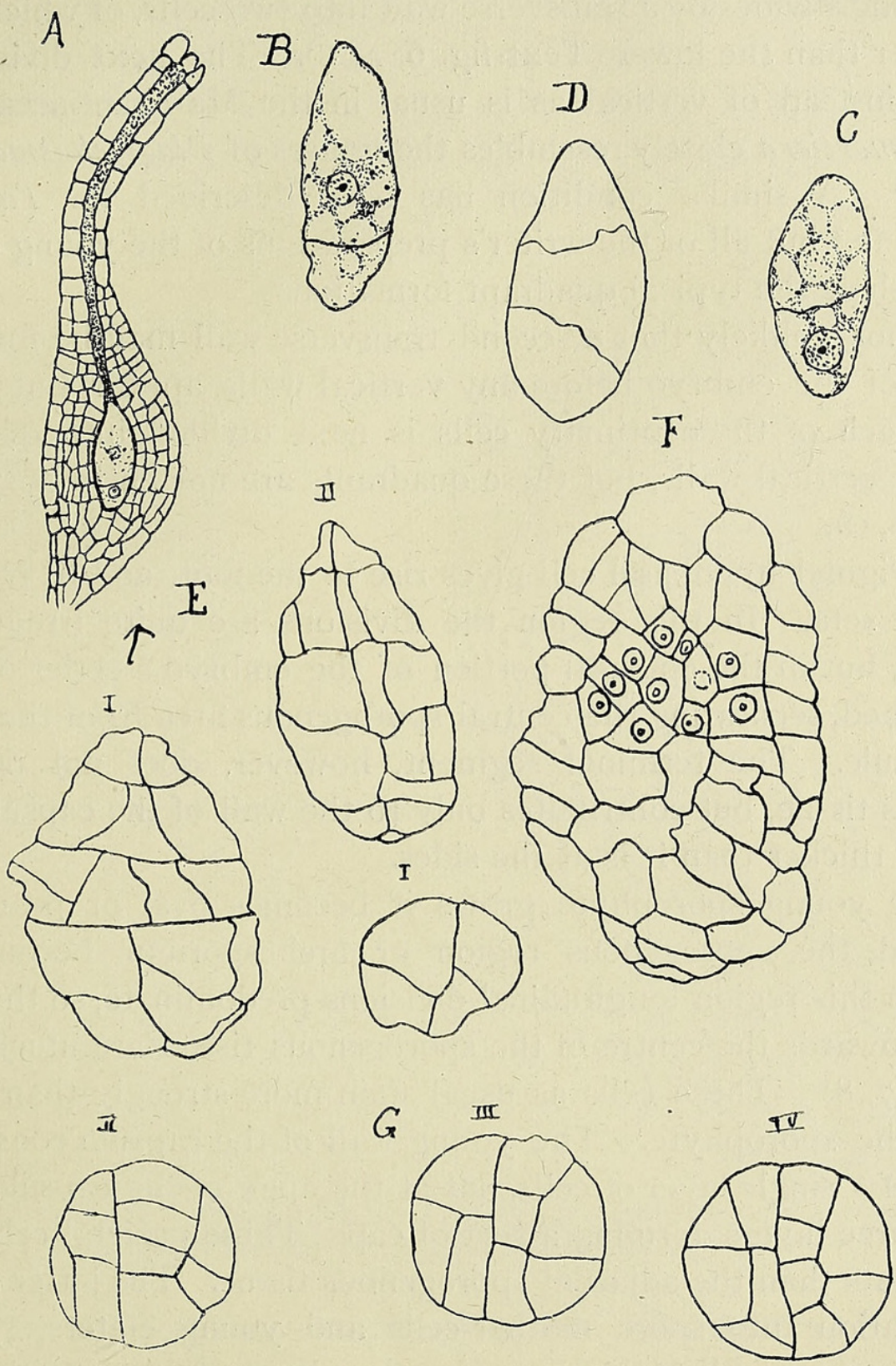

TeXT-FIG. 6. All figures refer to $D$. velutina. A. Archegonium containing a two-celled embryo. $\times 115$. B. Another section of the same embryo. $\times 28_{5}$. C. A similar embryo. $\times 285$. D. Three-celled embryo. $\times 285$. E. Two sections of an older embryo. $\times 285 . \quad 1$ is a nearly median section. F. An older embryo; the cells of the sporogenous tissue have their nuclei shown. $\times 285$. G. Four slightly oblique transverse sections of a young embryo. $\times 285$. I is the basal section of the series.

of Dumortiera has been published. The recent important work of Meyer, ${ }^{1}$ dealing with the embryo of the Marchantiales, does not include Dumortiera, nor make any references to the work of others on its embryo.

1 Meyer, K. : A Study of the Sporophyte of the Marchantiales (Russian). Moscow, igi6. 
The earlier stages of the embryo were found only in $D$. velutina; but as the later stages in $D$. trichocephala agree very closely with those in $D$. velutina, it may be assumed that there are no very great differences in the young embryos of the two species.

The fertilized egg, after developing a membrane about itself, becomes elongated and divides by a transverse wall into two cells, of which the upper one is larger than the lower (Text-fig. $6, \mathrm{~A}, \mathrm{C}$ ). The next division is also transverse instead of vertical as is usual in the Marchantiaceae. In this respect Dumortiera closely resembles the figures of Plagiochasma, described by Meyer. ${ }^{1}$ A similar condition has been described for Targionia by Miss O'Keefe, ${ }^{2}$ but all of the writer's preparations of the young embryos of Targionia show the typical quadrant formation. ${ }^{3}$

It is not unlikely that a second transverse wall may be formed in the upper cell of the embryo before any vertical walls appear, but this is not certain. Each of these primary cells is next divided into quadrants by intersecting vertical walls, but these quadrants are not entirely symmetrical (Text-fig. 6, G).

The original hypobasal cell gives rise to the foot, and to part, at least, of the short seta. In this region the divisions are quite irregular (Textfig. $6, \mathrm{E}, \mathrm{F})$, but in the epibasal portion of the embryo a series of periclinal walls is formed, separating the central sporogenous area from the wall of the future capsule. The terminal segment, however, does not develop any sporogenous tissue, but contributes only to the wall of the capsule, which at the apex is thicker than it is at the sides.

As the young sporophyte grows it becomes oval or pear-shaped in outline, and the sporogenous region or archesporium becomes clearly defined. In this region longitudinal divisions predominate, so that the cells, especially towards the centre of the sporogenous tissue, are much elongated (Text-figs. 7, 8). These cells as usual stain more strongly than the sterile tissues of the sporophyte. The young wall of the capsule consists for the most part of a single layer of cells, but at the apex of the capsule it consists of two or three layers, forming a sort of cap. These parietal cells have less dense contents than the adjacent sporogenous tissue. The latter soon shows a differentiation into spore mother-cells and young elaters. The spore mother-cells are usually in more or less regular rows, due to the repeated transverse divisions of some of the archesporial cells, while the others remain undivided and develop into elaters.

The lower part of the sporophyte develops a short seta merging gradually into a not very well-defined foot. The seta is somewhat better

1 Loc. cit., Figs. 35,36 .

2 O'Keefe, Lillian : Structure and Development of Targionia hypophylla. New Phytologist. vol, xiv, I9I5, pp. I05-16.

3 Campbell : loc. cit., Fig. 23. 

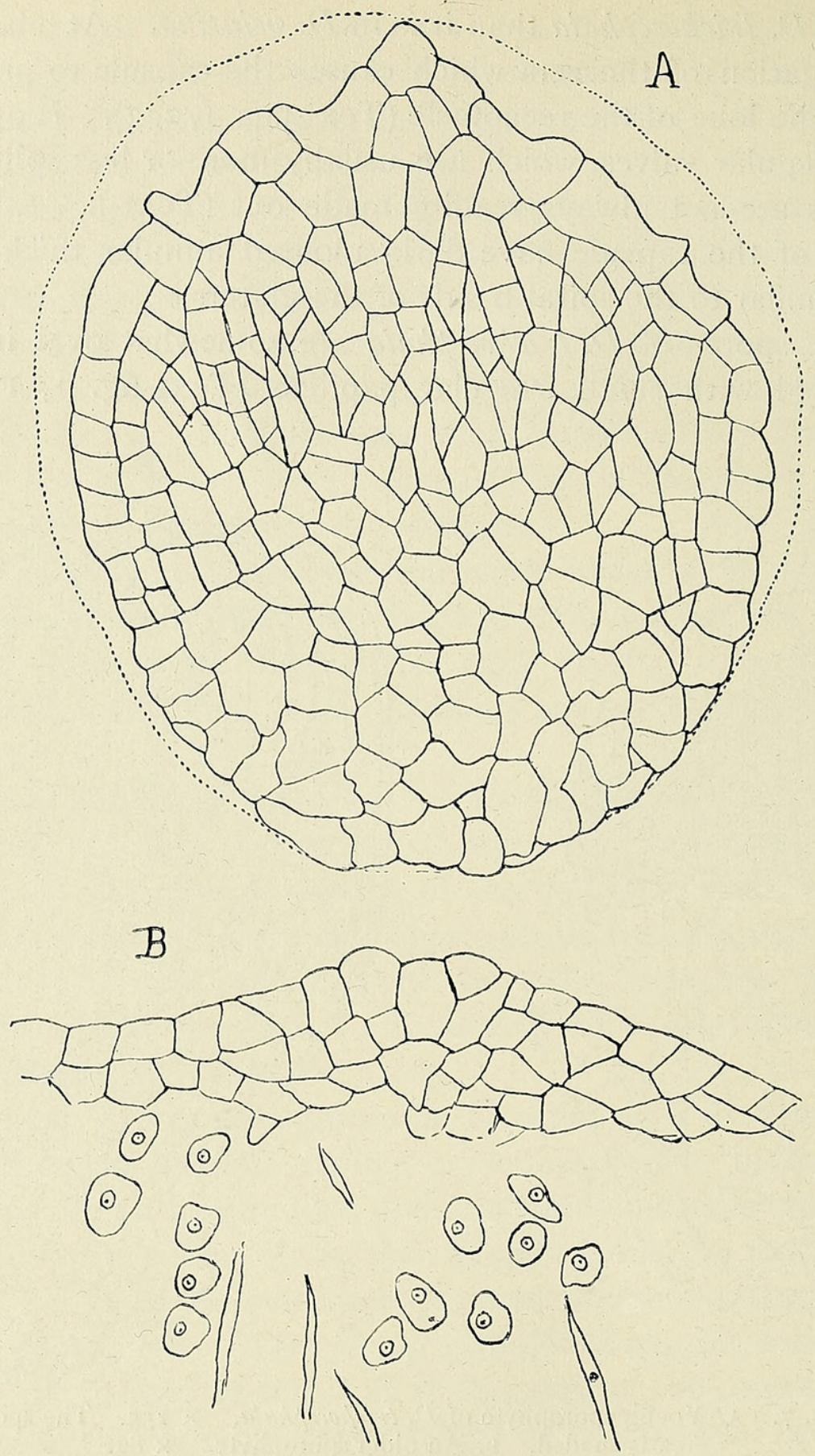

TEXT-F1G. 8. A. Young sporophyte of D. velutina. $\times 255 . \quad$ B. Apex of an older sporophyte, showing spore mother-cells and young elaters. $\times 255$.

\section{Dumortiera calcicola, sp. nov.}

While collecting in Borneo, the writer found what is apparently an undescribed species of Dumortiera - certainly very distinct from the two species already considered in this paper. The name D. calcicola is proposed for this plant, as it was found in all cases growing upon limestone débris or over outcrops of limestone.

The first specimens collected, which were all sterile, occurred in patches of considerable size upon loose heaps of débris at the foot of the limestone 
cliffs in which are excavated the Bidi Caves, not far from Bau, in Sarawak. At Bau other specimens were collected growing on the ground close to outcrops of limestone. These specimens were fertile, that is, they bore both male and female receptacles; but no sporophytes could be found. The substratum where these fertile plants were growing was much moister than the heaps of soft lime-dust upon which the plants first collected were growing, and this probably accounts for their greater luxuriance and the development of receptacles.

The sterile plant (Pl. VIII, Fig. I, A) is a delicate ribbon-like thallus with a faint midrib. In colour it resembles $D$. trichocephala, a dull olivaceous green, but is very much smaller than that species-or indeed than any other species of Dumortiera. The largest sterile specimens measured barely $5 \mathrm{~mm}$. in breadth, while some of the larger forms of D. trichocephala may be more than five times as wide (see Text-fig. 1, A).

The fertile plant (Pl. VIII, Fig. I, B-D, Fig. 2) differs so much in appearance from the sterile one that it was not at first recognized as the same species. The fertile branches are deeply lobed, so that they look as if there was a row of leaves on either side. Corresponding to each pair of lobes is a receptacle, sometimes five or six of these being formed in succession. Both male and female receptacles occur in the series, the firstformed one being usually, at least, male. It is not always possible to determine by a superficial examination whether the receptacle is male or female, but the former is usually more distinctly lobed than the female. So far as could be determined from the material at hand, both male and female receptacles are sessile; but as no sporophytes could be found, although both archegonia and antheridia were abundant, it may be that after fertilization the female receptacle develops a pedicel as in the other species of Dumortiera.

It was supposed when the specimens were collected that the receptacles were really dorsal outgrowths of the thallus; but further examination showed them to be really terminal structures, as in most other Marchantiaceae. Each receptacle terminates a shoot, and all except the first-formed one are borne on short adventitious branches which arise on the ventral side of the next younger shoot, near the apex. These short heart-shaped shoots, each bearing a receptacle at the apex, and closely linked together, give the series the appearance of a single leafy shoot, with a receptacle corresponding to each pair of leaves. Goebel ${ }^{1}$ has noted the same phenomenon, though less marked, in the peculiar genus Monoselenium; and it is possible that when the sporophyte of $D$. calcicola is found it may show that this plant is more nearly related to Monoselenium than it is to Dumortiera. It may be said, however, that sometimes in D. trichocephala similar adventitious branches are found (Text-fig. 2, B).

1 Goebel, K. : Archegoniatenstudien, XIII. Flora, vol. cl, I9Io, pp. 43-97. 
D. calcicola sometimes produces androgynous receptacles like those found in D. trichocephala.

The branching of the sterile plants of $D$. calcicola is prevailingly dichotomous; but in the fertile plants adventitious branches are sometimes very freely developed in addition to those which bear the receptacles (Pl. VIII, Fig. 2).

A section through the apex of the sterile shoot (Pl. VIII, Fig. 4) shows very clearly the formation of imperfect air-chambers; but, as in other species of Dumortiera, these are open above, and no proper stomata are developed. In the older portions of the thallus the air-chambers consist of large shallow depressions whose bounding walls form a faint irregular areolation on the surface of the thallus (Pl. VIII, Fig. 3).

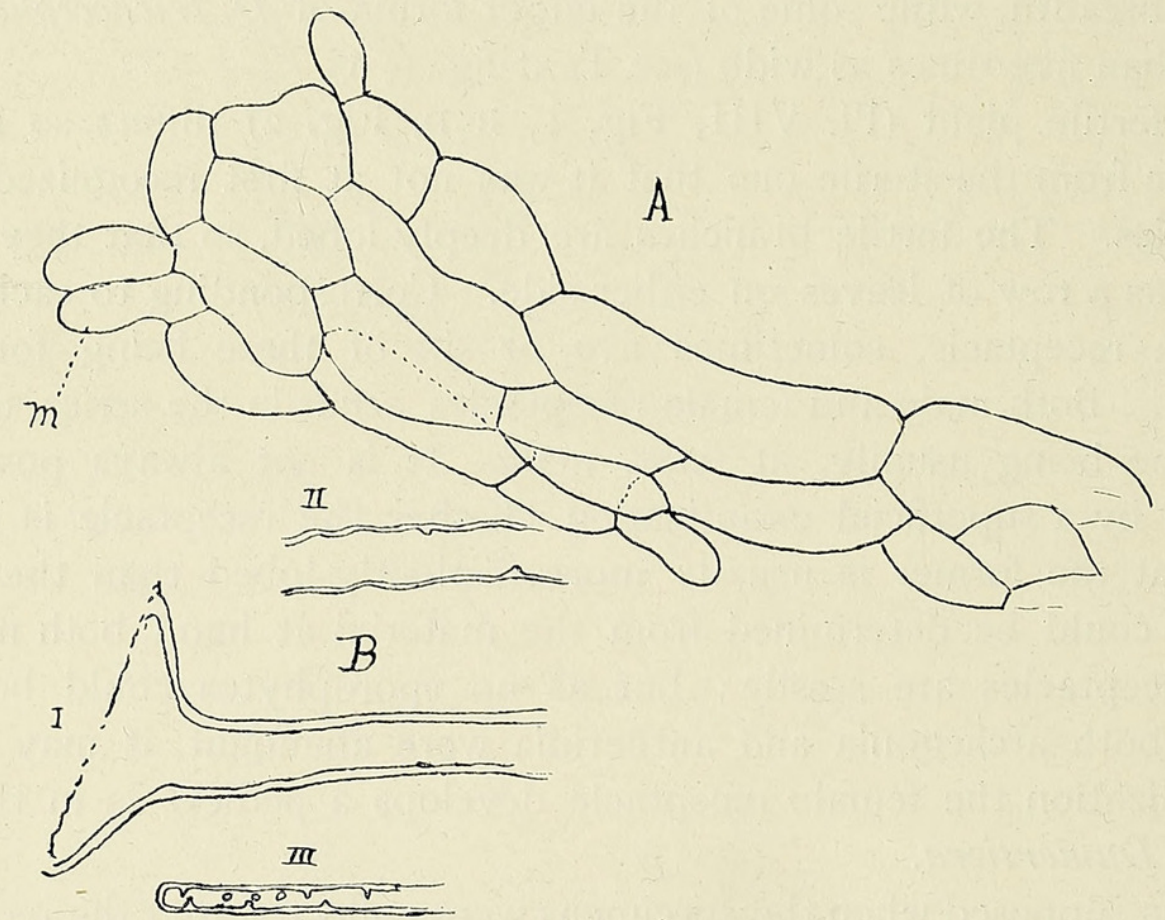

TeXT-FIg. 9. A. Ventral scale. B. Three rhizoids from the thallus of D. calcicola. $\times 285$.

The short green cell-rows which are so conspicuous on the floor of the air-chambers of Marchantic and Fegatella, for example, in D. calcicola are reduced to rounded papillate cells scattered over the surface of the thallus. These cells are more abundant than in $D$. trichocephala. Like the latter species there are stiff hairs on the margin of the thallus as well as fringing the receptacles, but these hairs are less numerous than in $D$. trichocephala.

A section of the older thallus (Pl. VIII, Fig. 5) shows a pretty well marked superficial layer of small cells, above and below, between which are very much larger cells. In the thinner part of the thallus the latter may be reduced to a single layer. As in all species of Dumortiera, the ventral scales are much reduced, and can only be recognized near the apex of the shoot. They are narrow spatulate structures, some of the marginal cells forming pear-shaped glands (Text-fig. 9, A, m). 
Rhizoids of three kinds are present-large smooth-walled ones, somewhat smaller ones with occasional tuberculate thickenings, and much smaller ones with numerous tubercles (Text-fig. 9, B).

The most striking character of $D$. calcicola is the arrangement of the receptacles. As has been stated already, male and female receptacles occur upon the same individual, and structurally these do not differ from those of other species of Dumortiera. Being of the composite type, the formation of a receptacle necessarily stops the growth of the shoot of which it is a part, and in most species the receptacle is obviously terminal, and only one receptacle is borne on the branch. In $D$. calcicola, however, as we have seen, there are apparently several receptacles formed in succession on the same branch, but this is not really the case. Soon after the first receptacle is formed an adventitious shoot appears close to the apex of the primary shoot on its ventral surface, and this shoot soon develops at its apex another receptacle; and the process may be repeated several times, so that there is a series of short branches, each bearing a receptacle, and so linked together as to give the appearance of a single deeply-lobed thallus bearing a series of dorsal receptacles.

Sometimes two of these adventitious shoots may develop almost simultaneously, thus simulating a dichotomy of the shoot apex (Pl. VIII, Fig. 2). The last-formed adventitious shoot may develop into an elongated sterile branch.

As a rule the primary receptacle bears antheridia, while the later ones are archegonial ; but secondary antheridial receptacles are not uncommon, and not infrequently androgynous receptacles occur.

The antheridial receptacle (Pl. VIII, Figs. 6,7 ) is usually 5-6 lobed, sometimes quite distinctly triangular in outline (Pl. VIII, Fig. I, B), while the female receptacle is nearly circular. Both have the margin beset with stiff hairs. On the ventral surface are irregular scales and numerous slender tuberculate rhizoids. The scales are especially noticeable in the younger stages, the subsequent dorsal growth of the receptacle pushing them under so that they are not visible from above.

The male receptacle and antheridia resemble those of the other species, except that they are decidedly smaller and the receptacle is often distinctly lobed. The antheridium has the elongated pedicel observed in the other species.

The young archegonial receptacle is somewhat intermediate in form between that of $D$. trichocephala and $D$. velutina. It is less convex than in the former, but more so than in $D$. velutina. The archegonia have the strongly curved neck observed in D. trichocephala (PI. VIII, Figs. 8, 9).

All of the female receptacles were sessile; but whether this is the case where the archegonia have been fertilized, or whether in such case a pedicel would develop as in all other species, is impošsible at present to say, since 
for some reason no fertilized archegonia or embryos were present in the material examined.

\section{Dumortiera calcicola, sp. nov.}

Thallus slender, olivaceous or brownish, $4-5 \mathrm{~cm}$. in length by $4-5 \mathrm{~mm}$. in width. Sterile shoots mostly dichotomous; fertile branches, except the primary ones, arising as adventitious shoots near the apex of the primary branch. Air-chambers evident; dorsal papillate cells rather numerous, but less so than in D. velutina. Ventral scales narrowly spatulate, inconspicuous; rhizoids numerous ; several $\left(5^{-6}\right)$ receptacles formed in succession on a series of terminal adventitious shoots. Antheridial receptacle sessile, often distinctly 5-6 lobed, about $2 \mathrm{~mm}$. in diameter. Archegonial receptacle sessile, similar in form and size to the male receptacle, but less evidently lobed. Sporophyte unknown.

On limestone soil ; Bidi Caves, Bau; Sarawak, Borneo, Feb. I9i 3.

\section{Wiesnerella denudata (Mitten), St.}

The genus Wiesnerella contains a single species, W. denudata (Mitten), St., ${ }^{1}$ which has been reported from four widely separated regions, viz. Java, the Himalayas, Japan, and Hawaii. ${ }^{2}$ Schiffner gave the name Wiesnerella Favanica to a Liverwort collected on Mt. Gedeh in Western Java. Stephani considers this to be identical with Dumortiera denudata, Mitten, originally described from the Himalayan region. Schiffner ${ }^{3}$ has given a clear diagnosis of the plant, but, so far as the writer is aware, did not study in detail the structure of the reproductive organs and sporophyte.

The material upon which the following account is based was collected by the writer near Tjibodas, on Mt. Gedeh, the locality from which Schiffner' specimens came.

Wiesnerella (Pl. IX, Fig. I3) in size is about the same as Dumortiera velutina, and in general habit is not unlike that species; but the colour is quite different, being a silvery green, quite different from the rich velvety green of $D$. velutina. This difference is due to the presence in Wiesnerella of a definite epidermis, with regular pores opening into perfectly developed air-chambers like those in most other Marchantiaceae. These air-chambers at once distinguish Wiesnerella from the evidently nearly related genus Dumortiera.

A vertical section of the apex of a sterile branch (Pl. IX, Figs. I6, I7) shows much the same structure as that found in Targionia or Fegatella. The wedge-shaped apical cell appears in this view as a triangle with alternate dorsal and ventral segments cut off from it. As usual, the growth in the dorsal region of the thallus is more active than in the tissue derived from the 
ventral segments of the apical cell. A short distance behind the apical cell, on the dorsal surface of the thallus, small depressions are evident between some of the cells. These are the first evidences of the series of dorsal airchambers. These in their further development do not show any departure from the type found in Targionia ${ }^{1}$ and Fegatella. ${ }^{2}$ The chamber opens at the surface by a simple pore or 'stoma' (P1. IX, Figs. I9, 20), and the floor of the chamber is occupied by papillate cells, which sometimes show a transverse division. These cells contain a few large chromatophores, and closely resemble those found on the free surface of the thallus in Dumortiera velutina.

The ventral scales are better developed than in Dumortiera. Each scale consists of a broad basal portion and a nearly semicircular terminal
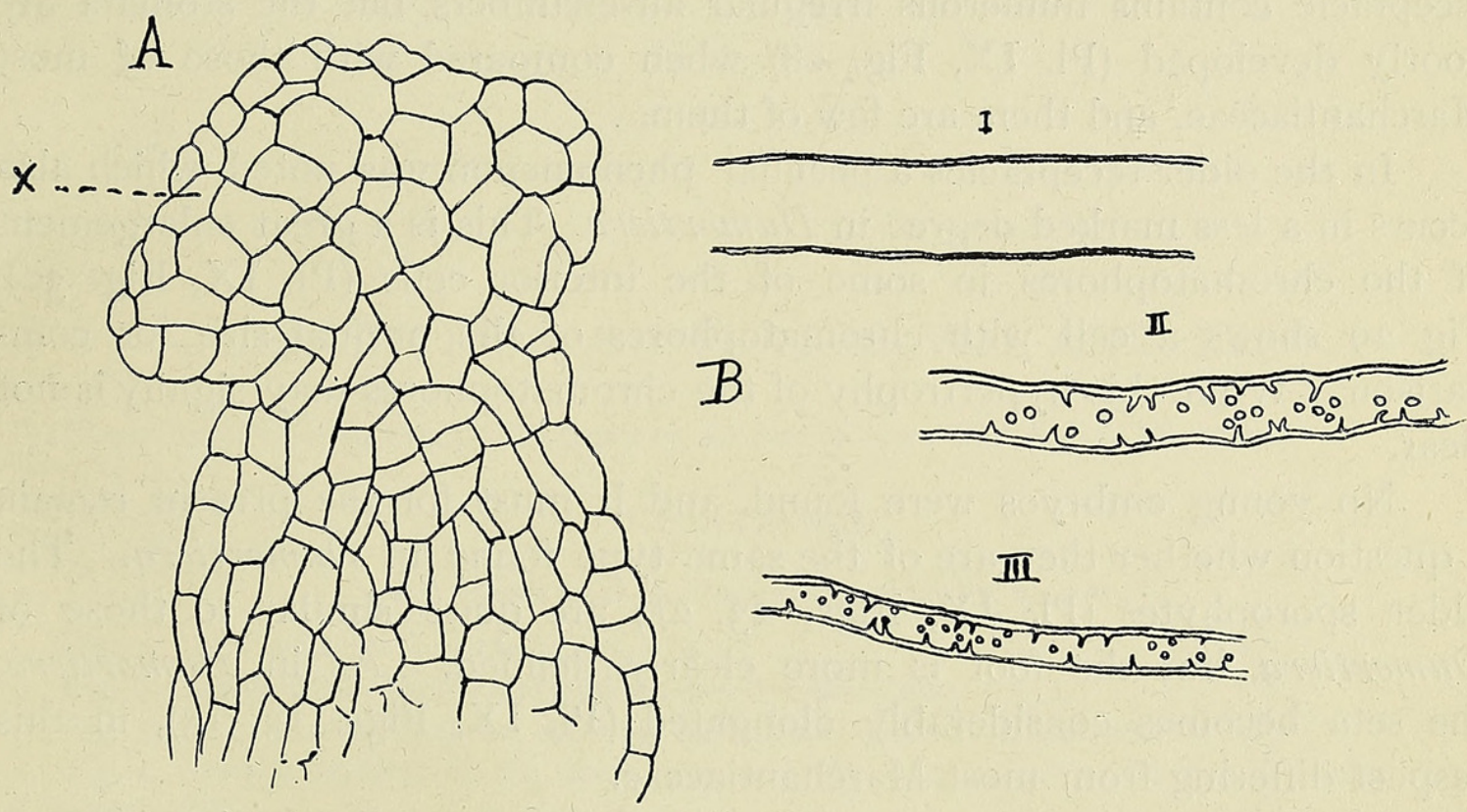

TEXT-Fig. Io. A. Ventral scale of Wiesnerella showing the terminal appendage $(x) . \quad \times 285$. B. Three rhizoids of Wiesnerella. $\times 285$.

appendage (Text-fig. IO, A). Numerous rhizoids, much like those in Dumortiera calcicola, are developed on the ventral surface of the thallus, especially along the axis (Text-fig. IO, B).

Wiesnerella is monoecious, the receptacles closely resembling those of Dumortiera, but the male receptacles are smaller than in either $D$. trichocephala or D. velutina. The carpocephalum (Pl. IX, Fig. I4) is symmetrically star-shaped, with usually $5^{-6}$ rays, and slightly convex. It is borne on a long, slender pedicel.

A few very young receptacles were found, showing that their early development is essentially the same as in Dumortiera; but material was not

1 Campbell : loc. cit., p. 48.

2 Cavers : On the Structure and Biology of Fegatella conica. Ann. of Bot., vol, xviii, I904, p. 87 . 
available for a study of the development of the sexual organs, and how far these may differ from those of Dumortiera remains to be seen. The adult archegonium, to judge from a small number of unfertilized archegonia that were seen (Fl. IX, Fig. 24), does not differ much from that of Dumortiera. The neck is straight, and in this respect it recalls $D$. velutina. As in Dumortiera, there is no special envelope or perianth about the archegonia, and the sporophyte, apart from the calyptra, is protected merely by the inrolled margin of the receptacle lobe, which forms a sort of pocket in which the sporophyte is quite concealed until it is ready to open.

The tissues of the carpocephalum are less specialized than is usual among the Marchantiaceae, and in this respect Wiesnerella shows its relationship to the still more reduced Dumortiera. The dorsal region of the receptacle contains numerous irregular air-chambers, but the stomata are poorly developed (Pl. IX, Fig. 28) when compared with those of most Marchantiaceae, and there are few of them.

In the older receptacles a peculiar phenomenon was noted, which also occurs in a less marked degree in Dumortiera. This is a great enlargement of the chromatophores in some of the interior cells (Pl, IX, Fig. 30). Fig. 29 shows a cell with chromatophores of the normal size for comparison. What this hypertrophy of the chromatophores may signify is not clear.

No young embryos were found, and it must for the present remain a question whether they are of the same type found in Dumortiera. The older sporophytes (Pl. IX, Figs. 23, 25) are quite similar to those of Dumortiera, but the foot is more clearly defined. As in Dumortiera, the seta becomes considerably elongated (Pl. IX, Figs. I3, I5), in this respect differing from most Marchantiaceae.

The ripe spores are very different from those of Dumortiera. They are very much larger $(60 \mu)$, and instead of the small papillae on the surface there are present very conspicuous wing-like ridges (P1. IX, Fig. 27).

\section{CONCLUSiON.}

It is pretty generally agreed that the most striking peculiarity of Dumortiera, i. e. the more or less complete obliteration of the air-chambers, is secondary and associated with the marked hygrophilous habit of most of the species. Of the species examined, $D$. velutina shows the least reduction, for not only are the outlines of the air-chambers quite evident, but the characteristic assimilative tissue is present in the form of very numerous superficial papillate cells. In $D$. trichocephala, which is more strongly hygrophilous in its habit, the reduction of the air-chambers is much more complete, and in one Hawaiian species (assumed to be D. trichocephala) the suppression is complete, as it is in the presumably related genus Monoselenium. 
Wiesnerella is especially interesting, as it is on the one hand unmistakably closely related to Dumortiera, while on the other it is obviously connected with the typical Marchantiaceae. It may be fairly said to connect forms of the type of Marchantia with the reduced Dumortiera. About the only evidence of reduction in Wiesnerella is the character of the stomata, especially those upon the receptacle.

The writer is indebted to Professor H. L. Lyon of Honolulu for mature specimens of the two Hawaiian species of Dumortiera. The carpocephala and spores of the smooth form are indistinguishable from those of the East Indian $D$. trichocephala. The other species is evidently not $D$. velutina, as suggested by the writer, but is probably $D$. hirsuta, which Stephani records for Hawaii.

\section{DESCRIPTION OF PLATES VIII AND IX.}

Illustrating Professor Campbell's paper on Studies on some East Indian Hepaticae.

\section{PLATE VIII.}

All figures refer to Dumortiera calcicola, sp. nov.

Fig. I. A, sterile; B-D, fertile plants. $\times 2$.

Fig. 2. Fertile plant, showing extensive adventive branching. $\times 2$.

Fig. 3. Apex of a sterile shoot, showing the outlines of the air-chambers. $\times 25$.

Fig. 4. Vertical section of the shoot-apex. $\times 380 . x$, apical cell; L-L, air-chambers; sc., ventral scale.

Fig. 5. Vertical section of the thallus. $\times 380$.

Fig. 6. Longitudinal section of a shoot, showing antheridial and young archegonial receptacles. $\times 50$.

Fig. 7. Outline of antheridial receptacle. $\times 25$.

Fig. 8. Section of young archegonial receptacle. $\times 9^{2}$.

Figs. 9-10. Archegonia. $\times 380$.

Fig. II. Outline of young archegonial receptacle. $\times 25 . \quad s c_{.}$, ventral scales.

Fig. 12. Antheridia. $\times 95$.

\section{PLATE IX}

All figures refer to Wiesnerella.

Fig. I3. Fertile specimen. $\times 2$.

Fig. I 4. Carpocephalum, seen from above. $\times 3$.

Fig. I5. Open sporogonium. $\times 5$.

Fig. 16. Median longitudinal section of the thallus, passing through the apex. $\times 125$.

Fig. 17. Apex of a shoot, showing the formation of the air-chambers, L. $\times 640$. $x$, apical cell.

Fig. I 8. Horizontal section of thallus-apex.

Fig. 19. Vertical section of air-chamber and stoma. $\times 3^{80 .}$ 


\section{Campbell.-Studies on some East Indian Hepaticae.}

Fig. 20. Surface view of a stoma.

Fig. 21. Section of young carpocephalum. $\times 380$. ar., young archegonium.

Fig. 22. Section of an older carpocephalum. $\times 58$.

Fig. 23. Nearly ripe carpocephalum, showing a sporophyte, $s p$, enclosed in the calyptra, cal. ar., unfertilized archegonia. $\times 50$.

Fig. 24. An unfertilized archegonium. $\times 140$.

Fig. 25. Nearly mature sporophyte. $\times 5^{8} . \quad d$, thickened apical portion of the wall.

Fig. 26. A pical region of a nearly ripe sporogonium. $\times 95^{\circ}$

Fig. 27 . A ripe spore and part of an elater. $\times 640$.

Fig. 28. Stoma from the carpocephalum. $\times 95$.

Fig. 29. A cell from the carpocephalum, showing normal chromatophores. $\quad \times 690$.

Fig. 30. Cell from the carpocephalum, showing much enlarged chromatophores. $\quad \times 640$. 
Anrals of Botany,

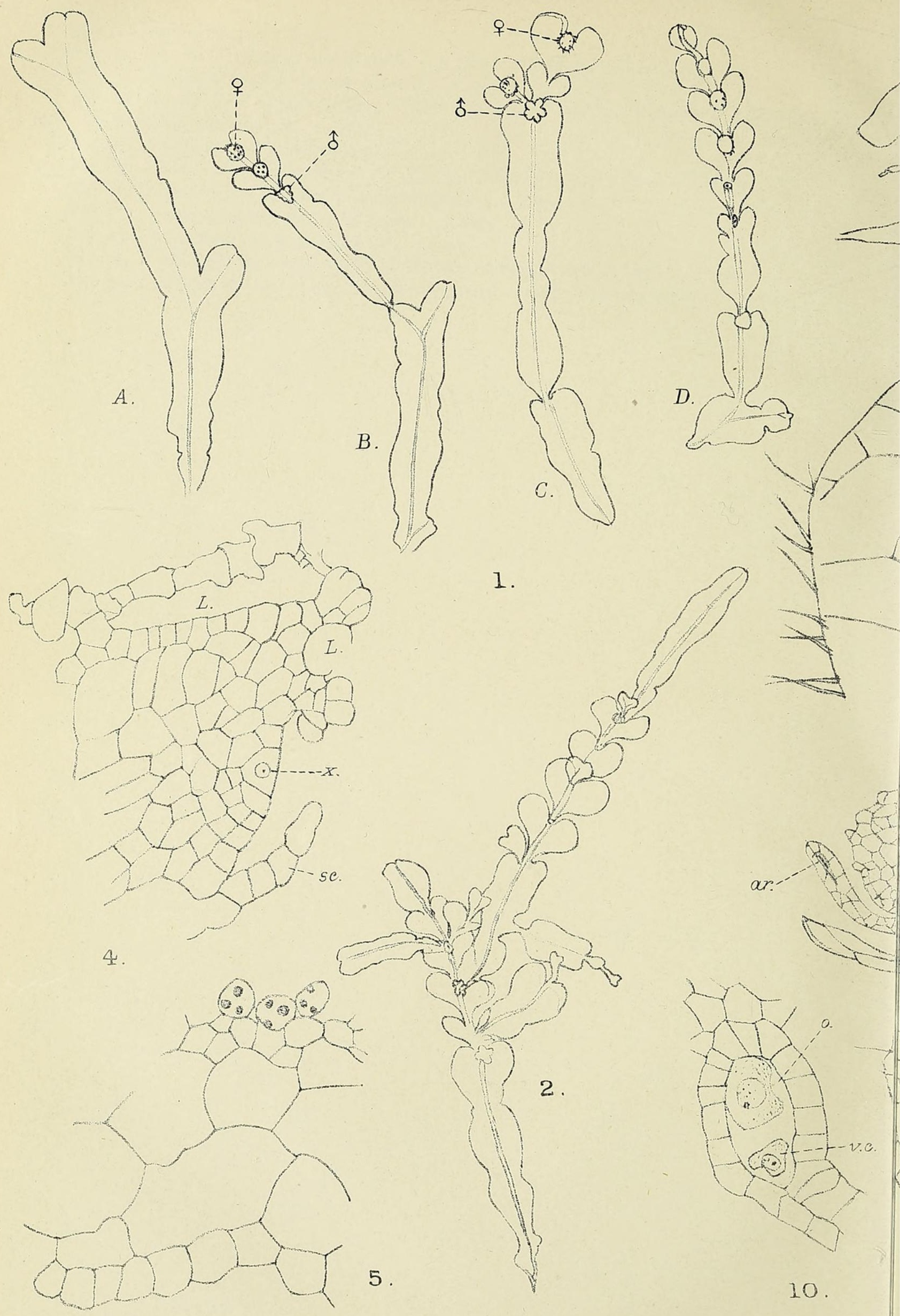

D.H.Campbell del.

CAMPBELL- HEPATICAE. 


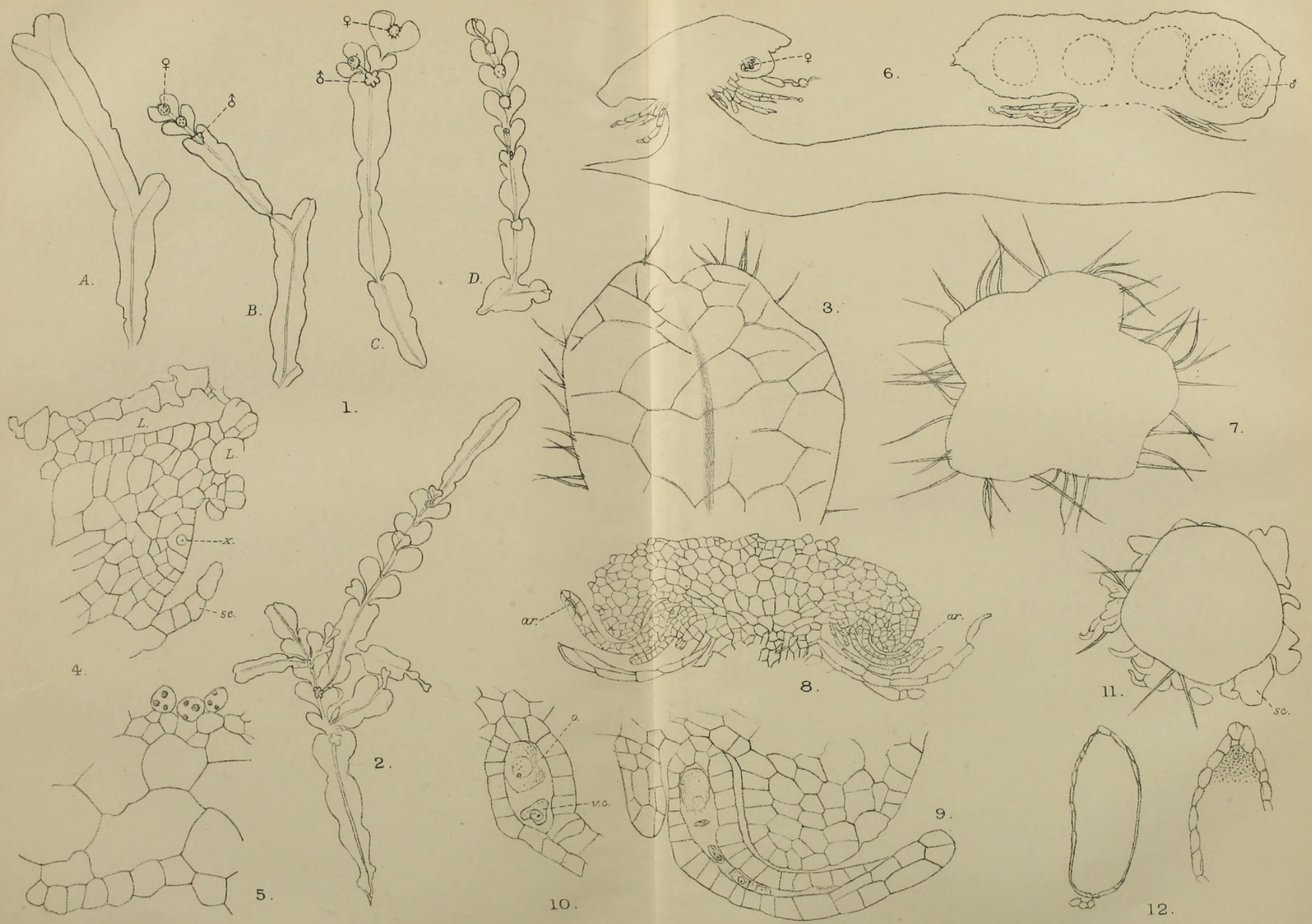


Annals of Botany,
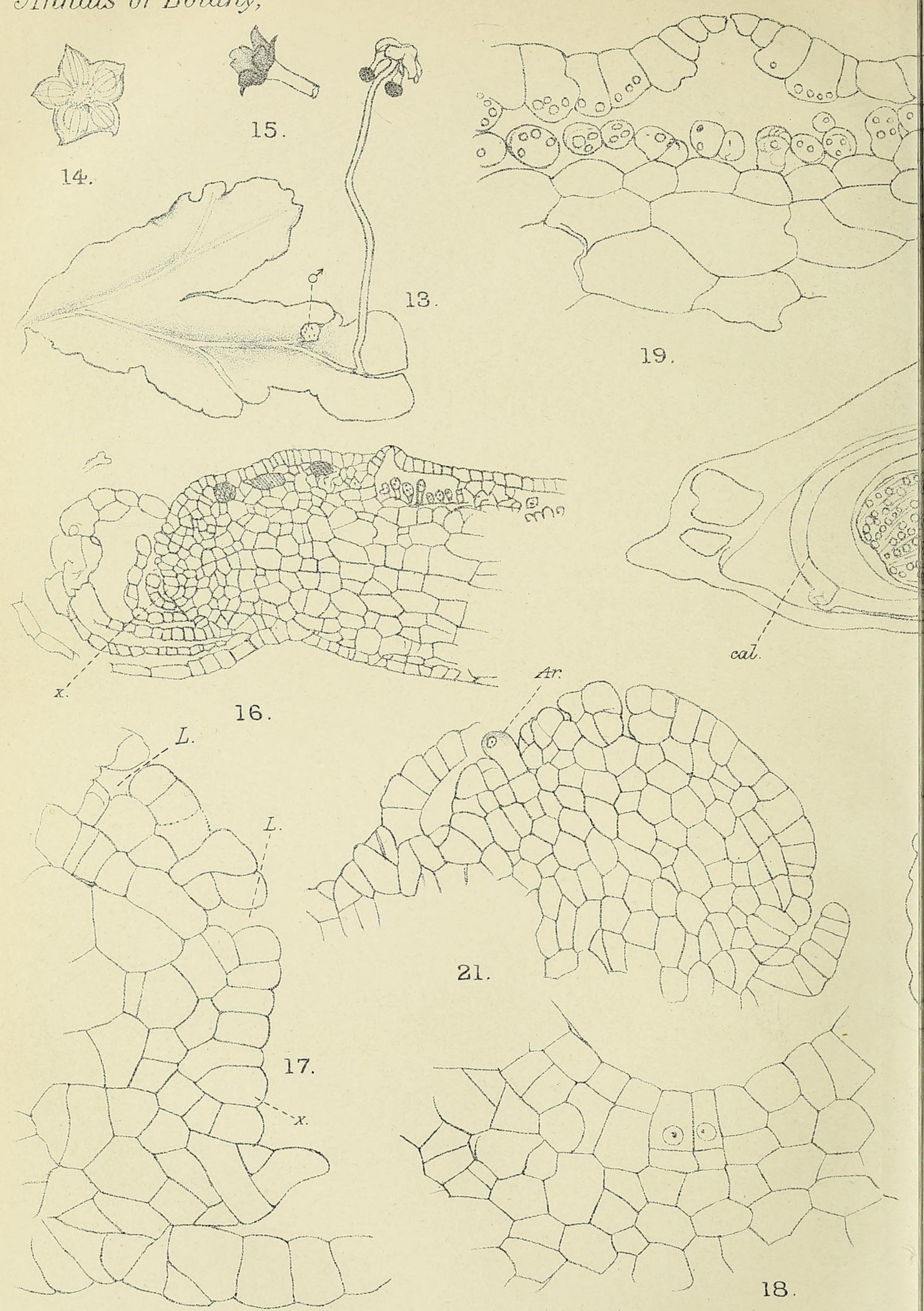

$13 x=A r$

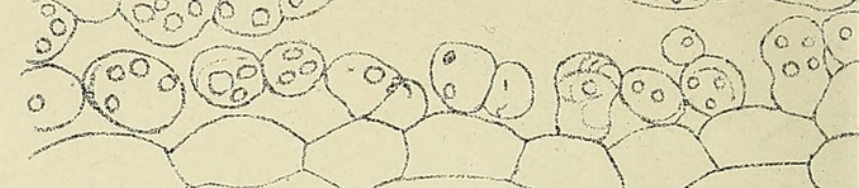




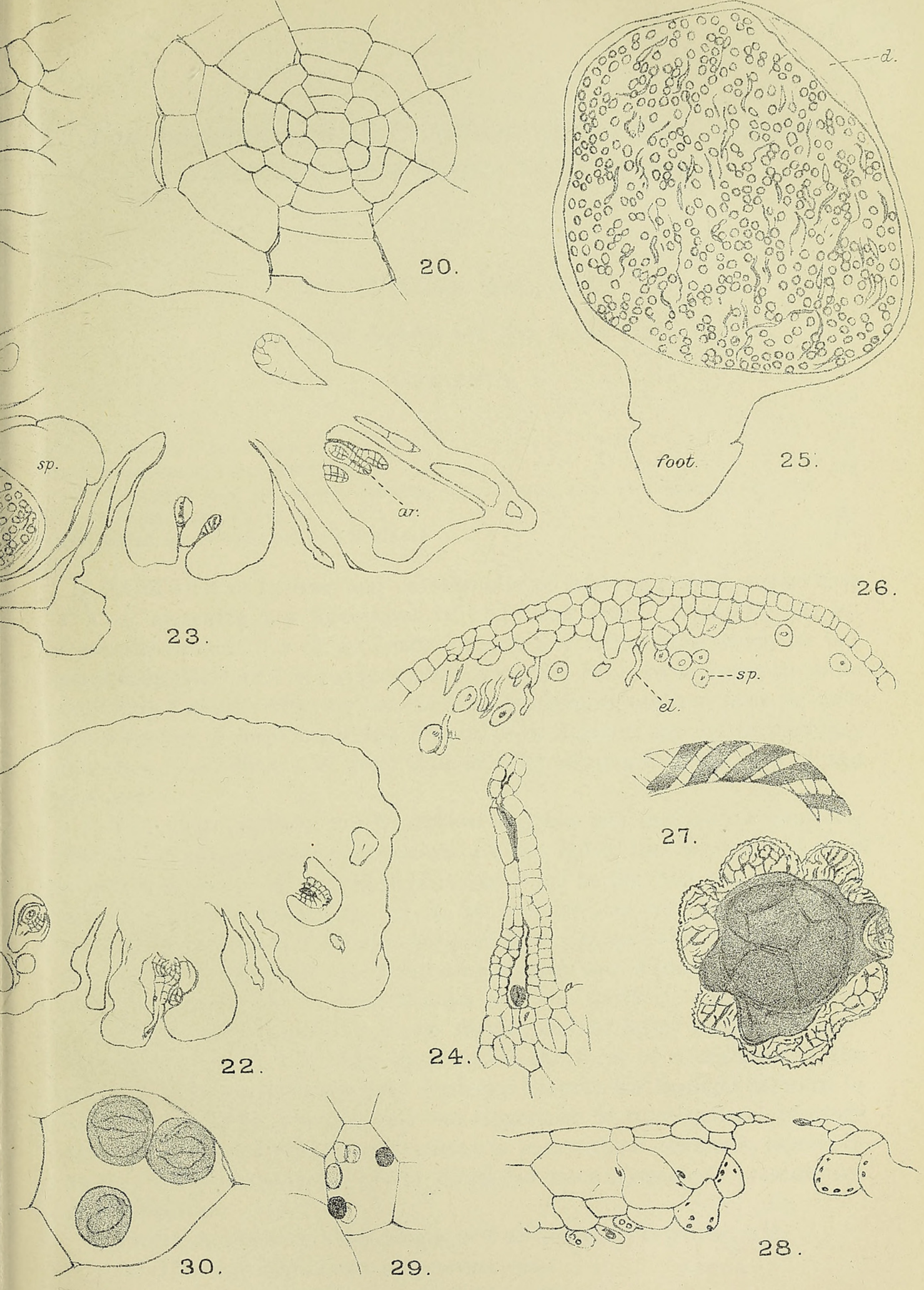

Huth,lith et imp 



\section{$2 \mathrm{BHL}$ Biodiversity Heritage Library}

Campbell, Douglas Houghton. 1918. "Studies on some East Indian Hepaticae." Annals of botany 32, 319-338.

https://doi.org/10.1093/oxfordjournals.aob.a089678.

View This Item Online: https://www.biodiversitylibrary.org/item/238284

DOI: https://doi.org/10.1093/oxfordjournals.aob.a089678

Permalink: https://www.biodiversitylibrary.org/partpdf/320221

\section{Holding Institution}

Smithsonian Libraries

\section{Sponsored by}

Biodiversity Heritage Library

\section{Copyright \& Reuse}

Copyright Status: Not in copyright. The BHL knows of no copyright restrictions on this item.

This document was created from content at the Biodiversity Heritage Library, the world's largest open access digital library for biodiversity literature and archives. Visit BHL at https://www.biodiversitylibrary.org. 